\title{
Evidence of Fenton-like reaction with active chlorine during the electrocatalytic oxidation of Acid Yellow 36 azo dye with Ir-Sn-Sb oxide anode in the presence of iron ion
}

\author{
Zaira G. Aguilar ${ }^{\mathrm{a}}$, Enric Brillas ${ }^{\mathrm{b}}$, Mercedes Salazar ${ }^{\mathrm{c}}$, José L. Nava ${ }^{\mathrm{a}, *}$, Ignasi Sirés ${ }^{\mathrm{b}, *}$ \\ a Departamento de Ingeniería Geomática e Hidráulica, Universidad de Guanajuato, Av. Juárez 77, Zona Centro, C.P 36000 Guanajuato, Guanajuato, Mexico \\ ${ }^{\mathrm{b}}$ Laboratori d'Electroquímica dels Materials i del Medi Ambient, Departament de Química Física, Facultat de Química, Universitat de Barcelona, Martí i Franquès 1-11, 08028 \\ Barcelona, Spain \\ ${ }^{c}$ Departamento de Ingeniería en Minas, Metalurgía y Geología, Universidad de Guanajuato, ExHacienda San Matías S/N, C.P. 36020, Guanajuato, Guanajuato, Mexico
}

\section{A R T I C L E I N F O}

\section{Article history:}

Received 18 November 2016 Received in revised form 1 January 2017

Accepted 3 January 2017

Available online $\mathrm{xxx}$

\section{Keywords:}

Azo dye

Mixed metal oxide

Electrochemical oxidation

Hydroxyl radical

Fenton-like process

Wastewater treatment

\section{A B S T R A C T}

The degradation of $2.5 \mathrm{~L}$ of Acid Yellow 36 solutions at $\mathrm{pH} 3.0$ by electro-oxidation (EO) has been studied in a flow plant with a reactor containing an Ir-Sn-Sb oxide anode and a stainless steel cathode. The anode was prepared onto Ti by the Pechini method and characterized by SEM-EDX and XRD. It showed a certain ability to electrocatalyze both, the generation of adsorbed ${ }^{\bullet} \mathrm{OH}$ from water oxidation in sulfate medium and, more largely, the production of active chlorine in a mixed electrolyte containing $\mathrm{Cl}^{-}$ion. The EO treatment of the dye solution in the latter medium led to a rapid decolorization because active chorine destroyed the colored by-products formed, but color removal was much slower in pure $\mathrm{NaClO}_{4}$ or $\mathrm{Na}_{2} \mathrm{SO}_{4}$ due to the limited formation of ${ }^{\bullet} \mathrm{OH}$. In contrast, greater mineralization was obtained in both pure electrolytes since the by-products formed in the presence of $\mathrm{Cl}^{-}$became largely persistent. The effect of liquid flow rate, current density and dye content on the EO performance in the mixed electrolyte was examined. The drop of absorbance and dye concentration obeyed a pseudo-first-order kinetics. Interestingly, the decolorization rate, dye concentration decay and TOC removal were enhanced upon catalysis with $1.0 \mathrm{mM} \mathrm{Fe}^{2+}$. Such better performance can be accounted for by the formation of ${ }^{\bullet} \mathrm{OH}$ in the bulk from the electro-Fenton-like reaction between electrogenerated $\mathrm{HClO}$ and added $\mathrm{Fe}^{2+}$. Even larger mineralization was achieved by the photoelectro-Fenton-like process upon irradiation of the solution with UVA light due to photolysis of some refractory intermediates. Maleic and acetic acids were detected as final short-chain linear carboxylic acids. The loss of $\mathrm{Cl}^{-}$and the formation of $\mathrm{ClO}_{3}{ }^{-}, \mathrm{ClO}_{4}{ }^{-}, \mathrm{SO}_{4}{ }^{2-}, \mathrm{NO}_{3}{ }^{-}$and $\mathrm{NH}_{4}{ }^{+}$were evaluated as well.

C 2016 Published by Elsevier Ltd.

\section{Introduction}

About $70 \%$ of the world dye production corresponds to azo compounds [1], which have a complex chemical structure containing one or various azo groups $(-\mathrm{N}=\mathrm{N}-)$ as chromophore, linked to aromatic systems with lateral groups including $-\mathrm{OH},-\mathrm{CH}_{3}$ and ${ }^{-} \mathrm{SO}_{3}{ }^{-}$, among others [2-4]. These dyes are extensively employed in textile industries, which are highly polluting in terms of the color, volume and complexity of their discharged effluents $[5,6]$. Dye wastewater contains dye concentrations up to $250 \mathrm{mg} \mathrm{L}^{-1}$, along with other toxic components, thus causing aesthetic problems, scarce light penetration and health problems to aquatic organisms owing to their carcinogenic, toxic and mutagenic properties [7,8]. The resistance to biodegradation and poor destruction of these pollutants by conventional treatments in wastewater treatment plants explain their large persistence in the aquatic environment $[4,9,10]$. Research is thus focusing on the development of more powerful treatments to remove

* Corresponding authors.

Email addresses: jlnm@ugto.mx (J.L. Nava); i.sires@ub.edu, isiresa@gmail.com (I. Sirés) azo dyes from wastewater in order to avoid their hazardous effects on living beings.

Several electrochemical advanced oxidation processes (EAOPs), including electro-oxidation (EO, also called electrochemical oxidation or anodic oxidation) and processes based on Fenton's reaction like electro-Fenton (EF), have been recently utilized to efficiently destroy azo dyes $[4,11-30]$. EAOPs are easy to handle and very versatile, also presenting high energy efficiency, great effectiveness to oxidize organic pollutants and environmental compatibility. They show great ability for the in situ production of reactive oxygen species (ROS), like hydroxyl radical $\left({ }^{\bullet} \mathrm{OH}\right)$ with such a high oxidation power $\left(E^{\circ}=2.80 \mathrm{~V} / \mathrm{SHE}\right)$ that it can non-selectively attack most organic pollutants until their mineralization $[4,21,23,30]$.

EO is the simplest EAOP applied to wastewater treatment. The most basic setup consists in an electrolytic cell containing the polluted wastewater in contact with a cathode and a large $\mathrm{O}_{2}$-overvoltage anode (M) that catalyzes the generation of adsorbed $\mathrm{M}\left({ }^{\bullet} \mathrm{OH}\right)$ radical from water oxidation at high applied current density $(j)$ as follows [31,32]:

$$
\mathrm{M}+\mathrm{H}_{2} \mathrm{O} \rightarrow \mathrm{M}(\cdot \bullet \mathrm{OH})+\mathrm{H}^{+}+\mathrm{e}^{-}
$$


The production of $\mathrm{M}\left({ }^{\bullet} \mathrm{OH}\right)$ radical depends on the kind of anode. At so-called active anodes such as $\mathrm{Pt}, \mathrm{IrO}_{2}$ and $\mathrm{RuO}_{2}, \mathrm{M}\left({ }^{\bullet} \mathrm{OH}\right)$ is transformed into a less powerful oxidant like chemisorbed "superoxide" MO $[19,33]$. Such conversion can be minimized when using non-active anodes like $\mathrm{PbO}_{2}, \mathrm{SnO}_{2}$ and boron-doped diamond (BDD), which promote high contents of physisorbed $\mathrm{M}\left({ }^{\bullet} \mathrm{OH}\right)$ leading to the mediated electrochemical incineration of organic pollutants on the anode $[11,12,18,34,35]$. It has been found that several active mixed metal oxide (MMO) anodes yield larger degradation than pure metal oxides, as reported for phenol and Reactive Orange 4 using Ti/ $\mathrm{SnO}_{2}-\mathrm{Sb}_{2} \mathrm{O}_{3}$ and $\mathrm{Ti} / \mathrm{SnO}_{2}-\mathrm{Sb}-\mathrm{Pt}$, respectively [36].

This general description is valid when the EO treatment is performed in the presence of anions like $\mathrm{ClO}_{4}{ }^{-}, \mathrm{NO}_{3}{ }^{-}$and $\mathrm{SO}_{4}{ }^{2-}$, which remain stable during the electrolysis or become a source of weak oxidants, e.g., $\mathrm{S}_{2} \mathrm{O}_{8}{ }^{2-}$ at the $\mathrm{BDD}$ surface [31,32]. In contrast, the EO process becomes much more complex in the presence of $\mathrm{Cl}^{-}$because it can be oxidized to active chlorine $\left(\mathrm{Cl}_{2}, \mathrm{HClO}\right.$ and/or $\left.\mathrm{ClO}^{-}\right)$ via Reactions (2)-(4), which competes with $\mathrm{M}\left({ }^{\bullet} \mathrm{OH}\right)$ to attac ${ }^{*}$ cules $[1,4,21-23,26,37,38]$.

$$
\begin{aligned}
& \mathrm{Cl}^{-} \rightarrow \mathrm{Cl}_{2(\text { aq })}+2 \mathrm{e}^{-} \\
& \mathrm{Cl}_{2(\text { aq })}+\mathrm{H}_{2} \mathrm{O} \rightleftarrows \mathrm{HClO}+\mathrm{Cl}^{-}+\mathrm{H}^{+} \\
& \mathrm{HClO} \rightleftarrows \mathrm{ClO}^{-}+\mathrm{H}^{+}
\end{aligned}
$$

The predominant active chlorine species is $\mathrm{Cl}_{2(\mathrm{aq})}\left(E^{\circ}=1.36 \mathrm{~V} /\right.$ SHE) until $\mathrm{pH} 3.0, \mathrm{HClO}\left(E^{\circ}=1.49 \mathrm{~V} / \mathrm{SHE}\right)$ within the $\mathrm{pH}$ range 3-8 and $\mathrm{ClO}^{-}\left(E^{\circ}=0.89 \mathrm{~V}\right.$ vs. SHE$)$ at $\mathrm{pH}>8.0$. The mediated electrochemical oxidation of organics with these species is then expected to be more successful in acidic medium. On the other hand, Kishimoto et al. [39] recently suggested the enhanced decontamination of acidic wastewater containing $\mathrm{Cl}^{-}$through the generation of ${ }^{\bullet} \mathrm{OH}$ in the bulk using $\mathrm{Fe}^{2+}$ and $\mathrm{HClO}$ via Fenton-like Reaction (5) [40]. Note that, actually, this corresponds to an EF-like process in which Reaction (5) replaces the classical Fenton's reaction between $\mathrm{H}_{2} \mathrm{O}_{2}$ and $\mathrm{Fe}^{2+}$ catalyst to form $\mathrm{Fe}^{3+}$ and $\bullet \mathrm{OH}[4,23]$. Reaction (5) can thus be sustained from $\mathrm{Fe}^{2+}$ regeneration upon cathodic reduction of $\mathrm{Fe}^{3+}$ via Reaction (6). Additionally, one could envisage the production of larger amounts of $\bullet \mathrm{OH}$ from the photolytic reduction of $\mathrm{Fe}(\mathrm{OH})^{2+}$, the pre-eminent $\mathrm{Fe}^{3+}$ species at $\mathrm{pH} 3.0$, by Reaction (7) upon use of UVA radiation $[30,41]$. The latter photoelectrocatalytic treatment, which is reported for the first time, can be so-called PEF-like process.

$$
\begin{aligned}
& \mathrm{HClO}+\mathrm{Fe}^{2+} \rightarrow \mathrm{Fe}^{3+}+\cdot \mathrm{OH}+\mathrm{Cl}^{-} \\
& \mathrm{Fe}^{3+}+\mathrm{e}^{-} \rightarrow \mathrm{Fe}^{2+} \\
& \mathrm{Fe}(\mathrm{OH})^{2+}+h v \rightarrow \mathrm{Fe}^{2+}+\mathrm{OH}
\end{aligned}
$$

To give evidence of the upgrading of azo dye removal under EF-like and PEF-like conditions, we have undertaken a study on the degradation of Acid Yellow 36 in acidic chlorinated solutions using a purpose-made Ir-Sn-Sb oxide anode with ability to produce $\mathrm{M}\left({ }^{\bullet} \mathrm{OH}\right)$ radicals and active chlorine $[38,42]$. Acid Yellow 36 (also known as Metanil Yellow, see physicochemical properties in Table 1) has been chosen as model azo dye because it is present in wastewater from tex-
Table 1

Physicochemical properties of Acid Yellow 36 azo dye.

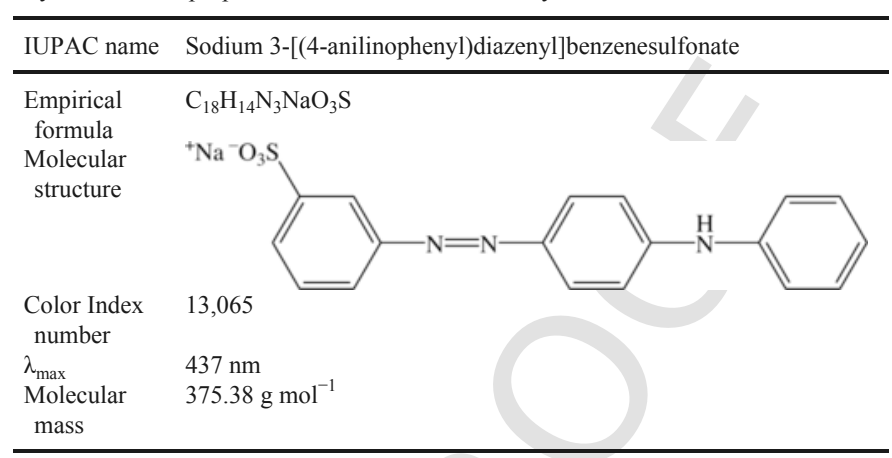

tile, tannery, paper and cosmetic industries, among others. This refractory dye is a toxic and carcinogenic pollutant that causes mortality and adverse health effects in fishes [43]. Its consumption by humans causes toxic methaemoglobinaemia and cyanosis, whereas its contact with skin produces allergic dermatitis [44]. Effective decolorization and/or mineralization of synthetic Acid Yellow 36 solutions upon the action of ${ }^{\bullet} \mathrm{OH}$ has been described by several AOPs including photocatalysis with $\mathrm{TiO}_{2}[45,46]$ and $\mathrm{ZnO}$ [47], Fenton [48] and photo-Fenton [49]. EAOPs such as EO [50], EF [14,51] and PEF [15] with BDD anode, as well as PEF combined with $\mathrm{TiO}_{2}$ photocatalysis [46], have also been employed but only in sulfate medium.

This article presents the results obtained for the degradation of a $0.46 \mathrm{mM}$ Acid Yellow 36 solution $\left(100 \mathrm{mg} \mathrm{L}^{-1}\right.$ of total organic carbon (TOC)) in a $35 \mathrm{mM} \mathrm{NaCl}+25 \mathrm{mM} \mathrm{Na}_{2} \mathrm{SO}_{4}$ mixture at $\mathrm{pH} 3.0$ by EO. The experiments were performed in a $2.5 \mathrm{~L}$ flow plant with a filter-press cell equipped with an Ir-Sn-Sb oxide anode and a stainless steel cathode. The anode was composed of an MMO film onto Ti plate prepared by the Pechini method [52]. It was characterized by scanning electron microscopy with energy dispersive X-ray spectroscopy (SEM-EDX) and X-ray-diffraction (XRD), whereas its electrocatalytic ability to generate ${ }^{\bullet} \mathrm{OH}$ and active chlorine was analyzed by electron paramagnetic resonance (EPR) and UV/vis spectroscopy, respectively. The effect of liquid flow rate, $j$ and dye concentration on decolorization rate and mineralization degree was examined. Comparative trials using pure $\mathrm{NaClO}_{4}$ or $\mathrm{Na}_{2} \mathrm{SO}_{4}$ as electrolyte were made to better assess the role of active chlorine in the mixed electrolyte. The influence of $\mathrm{Fe}^{2+}$ addition to the latter medium, either in the dark or under UVA irradiation, was studied to give strong evidence of the occurrence of a Fenton-like reaction. Intermediates and inorganic ions lost or released during the dye degradation were identified.

\section{Materials and methods}

\subsection{Chemicals}

Commercial Acid Yellow 36 (70\% of dye content, the rest corresponding to inorganic products) was purchased from Sigma-Aldrich and used as received. The products for the MMO synthesis were $\mathrm{H}_{2} \mathrm{IrCl}_{6} \cdot \mathrm{xH}_{2} \mathrm{O}, \mathrm{SnCl}_{4}$ and $\mathrm{SbCl}_{3}$ of analytical grade supplied by Sigma-Aldrich. The electrolytic solutions were prepared with deionized water and contained $\mathrm{FeSO}_{4} \cdot 7 \mathrm{H}_{2} \mathrm{O}, \mathrm{Na}_{2} \mathrm{SO}_{4}, \mathrm{NaOH}, \mathrm{NaCl}$ and/or $\mathrm{HClO}_{4}$ of analytical grade purchased from Fluka, Merck and Panreac. Analytical grade 5,5-dimethyl-1-pyrroline- $N$-oxide (DMPO) used for - OH detection was supplied by Sigma-Aldrich. Other chemicals were of either HPLC or analytical grade purchased from Fluka, Merck, Panreac and Sigma-Aldrich. 


\subsection{Synthesis of the mixed metal oxide electrode}

Titanium plates were initially pretreated by dipping them into concentrated $\mathrm{HCl}$ at $70^{\circ} \mathrm{C}$ for $1 \mathrm{~h}$, followed by immersion in concentrated $\mathrm{HNO}_{3}$ at room temperature for $15 \mathrm{~min}$, rinsing with distilled water and drying at room temperature. This pretreatment increased the material roughness to improve the adhesion of oxides. The precursor polymer solution to apply the Pechini method was prepared by mixing citric acid and ethylene glycol with molar proportion of $0.00750: 1$ at 60-70 ${ }^{\circ} \mathrm{C}$. After this, $\mathrm{SbCl}_{3}, \mathrm{SnCl}_{4}$ and $\mathrm{H}_{2} \mathrm{IrCl}_{6} \cdot \mathrm{xH}_{2} \mathrm{O}$ were added with molar proportion of 0.00012:0.00925:0.00925 for Sb:Sn:Ir, maintaining the temperature at $60-70{ }^{\circ} \mathrm{C}$ for $30 \mathrm{~min}$, as optimized in one of our previous works [19]. The resulting solution was applied to the Ti substrate using a brush and the electrode was then heated at $115^{\circ} \mathrm{C}$ for $15 \mathrm{~min}$ in a furnace for inducing the polymerization of the precursor, followed by heating at $550{ }^{\circ} \mathrm{C}$ for $10 \mathrm{~min}$ to calcinate the polymer and form the metal oxides. This procedure was repeated until achieving 32 coated layers, whereupon the electrode was heated at $550{ }^{\circ} \mathrm{C}$ for $1 \mathrm{~h}$.

\subsection{Bulk electrolysis}

A scheme of the flow plant used in this work and constructed by us has been reported elsewhere [15]. The $2.5 \mathrm{~L}$ acidic dye solution was introduced in a reservoir and recirculated with a peristaltic pump, regulating the liquid flow rate with a flowmeter and the temperature at $30^{\circ} \mathrm{C}$ with two heat exchangers. The electrochemical cell was a purpose-made filter-press-type reactor equipped with the prepared Ir-Sn-Sb oxide anode, a stainless steel plate cathode and a turbulence promoter Type D [35]. The anode and cathode area was $24 \mathrm{~cm}^{2}(8 \mathrm{~cm} \times 3 \mathrm{~cm})$ and the interelectrode gap was $0.6 \mathrm{~cm}$. The trials were carried out at constant $j$ provided by a Grelco GVD310 power supply. An annular glass photoreactor containing an Omnilux 27E 160-W UVA lamp, connected between the reactor and reservoir, was used for the PEF-like assays. Most experiments were performed with a $0.46 \mathrm{mM}$ Acid Yellow 36 solution in $35 \mathrm{mM} \mathrm{NaCl}+25 \mathrm{mM}$ $\mathrm{Na}_{2} \mathrm{SO}_{4}$. Several comparative assays were made with $50 \mathrm{mM} \mathrm{NaClO}_{4}$ or $50 \mathrm{mM} \mathrm{Na}_{2} \mathrm{SO}_{4}$. The initial $\mathrm{pH}$ of the acidic solution was always adjusted to 3.0 because it has been found optimal for the treatments of organics by conventional $\mathrm{EF}[4,23]$.

\subsection{Apparatus and analytical methods}

The morphological characteristics and composition of the synthesized MMO film were assessed with $2.0 \mathrm{~cm} \times 0.5 \mathrm{~cm}$ samples by SEM-EDX using a JSM-7100F field emission scanning electron microscope equipped with an INCA analyzer. The crystal structure was analyzed by XRD using a PANalytical X'Pert PRO MPD Alpha1 powder diffractometer in Bragg-Brentano $\theta / 2 \theta$ geometry with $240 \mathrm{~mm}$ radius. Reference diffraction patterns were selected from the ICDD database.

The hydroxyl radicals were detected by spin trapping, analyzing the ${ }^{\bullet} \mathrm{OH}-\mathrm{DMPO}$ adduct by EPR [53]. To do this, $10 \mathrm{~mL}$ of a $10 \mathrm{mM}$ DMPO solution at $\mathrm{pH} 3.0$ were electrolyzed in an undivided cell with a $1 \mathrm{~cm}^{2} \mathrm{Ir}-\mathrm{Sn}-\mathrm{Sb}$ oxide anode and a $1 \mathrm{~cm}^{2}$ stainless steel cathode at $j=20 \mathrm{~mA} \mathrm{~cm}^{-2}$ for $15 \mathrm{~min}$ under vigorous stirring with a magnetic bar at room temperature. The treated solution was immediately frozen with dry ice for preservation to be further analyzed by EPR with a Bruker ESP300E spectrometer, using Win-EPR and SimFonia 2.3 software.
Active chlorine was determined by the $N, N$-diethyl- $p$-phenylenediamine (DPD) colorimetric method using a Shimadzu $1800 \mathrm{UV} / \mathrm{vis}$ spectrophotometer set at $\lambda=515 \mathrm{~nm}$ [54]. The solution $\mathrm{pH}$ was determined with a Crison $2000 \mathrm{pH}$-meter. Color removal was monitored from the absorbance $(A)$ decay of its main visible band at $\lambda_{\max }=437 \mathrm{~nm}$, related to the conjugated azo bond [15], using the above spectrophotometer. The percentage of color removal or decolorization efficiency was then calculated as follows [4]:

$$
\text { Percentage of color removal }=\frac{A_{0}-A}{A_{0}} \times 100
$$

where $A_{0}$ and $A$ denote the absorbance of the initial solution and at time $t$, respectively.

Acid Yellow 36 mineralization was followed from the removal of solution TOC using a Shimadzu VCSN TOC analyzer. Samples withdrawn from initial and treated solutions were filtered with $0.45 \mu \mathrm{m}$ PTFE filters purchased from Whatman and $50 \mu \mathrm{L}$ aliquots were directly injected into the above analyzer, obtaining $1 \%$ accuracy in all triplicate measurements. TOC data allowed estimating the mineralization current efficiency (MCE) from Eq. (9) [15]:

$$
\% \mathrm{MCE}=\frac{n F V_{s} \Delta(T O C)_{\exp }}{4.32 \times 10^{7} \mathrm{mIt}} \times 100
$$

where $F$ is the Faraday constant $\left(96,485 \mathrm{C} \mathrm{mol}^{-1}\right), V_{\mathrm{s}}$ is the solution volume $(\mathrm{L}), \Delta(\mathrm{TOC})_{\exp }$ represents the experimental TOC removal $\left(\mathrm{mg} \mathrm{L}^{-1}\right), 4.32 \times 10^{7}$ is a conversion factor $\left(3600 \mathrm{~s} \mathrm{~h}^{-1} \times\right.$ $\left.12000 \mathrm{mg} \mathrm{C} \mathrm{mol}^{-1}\right), m=18$ is the number of carbon atoms of Acid Yellow 36, $I$ is the applied current (A) and $t$ is the electrolysis time (h). Considering the dye mineralization to $\mathrm{CO}_{2}$ and $\mathrm{SO}_{4}{ }^{2-}$ and $\mathrm{NO}_{3}{ }^{-}$ ions, as will be discussed below, the number $n$ of electrons required for the theoretical total mineralization of its anion form was taken as 102 from Eq. (10):

$$
\begin{aligned}
& \mathrm{C}_{18} \mathrm{H}_{14} \mathrm{~N}_{3} \mathrm{O}_{3} \mathrm{~S}^{-}+46 \mathrm{H}_{2} \mathrm{O} \rightarrow 18 \mathrm{CO}_{2}+\mathrm{SO}_{4}{ }^{2-}+3 \\
& \mathrm{NO}_{3}{ }^{-}+106 \mathrm{H}^{+}+102 \mathrm{e}^{-}
\end{aligned}
$$

The dye decay kinetics was followed by reversed-phase high-performance liquid chromatography (HPLC) using a Waters 600 LC fitted with a BDS Hypersil C18 $6 \mu \mathrm{m}, 250 \mathrm{~mm} \times 4.6 \mathrm{~mm}$, column at $35^{\circ} \mathrm{C}$ and coupled to a Waters 996 photodiode array detector selected at $\lambda=437 \mathrm{~nm}$. The mobile phase was a 50:50 (v/v) acetonitrile/water (phosphate buffer of $\mathrm{pH} 3.0$ ) mixture at $0.6 \mathrm{~mL} \mathrm{~min}^{-1}$. Samples were diluted with the same volume of $\mathrm{CH}_{3} \mathrm{CN}$ to stop the degradation of the dye. Aliquots of $20 \mu \mathrm{L}$ were injected into the LC and the chromatograms exhibited a well-defined peak related to Acid Yellow 36 at retention time $\left(t_{\mathrm{r}}\right)$ of $5.6 \mathrm{~min}$. Final carboxylic acids were quantified by ion-exclusion HPLC upon injection of $20 \mu \mathrm{L}$ of the same samples to the above LC with a BioRad Aminex HPX $87 \mathrm{H}, 300 \mathrm{~mm} \times 7.8 \mathrm{~mm}$ column, at $35^{\circ} \mathrm{C}$, selecting the photodiode array detector at $\lambda=210 \mathrm{~nm}$. The mobile phase was $4 \mathrm{mM} \mathrm{H}_{2} \mathrm{SO}_{4}$ circulating at $0.6 \mathrm{~mL} \mathrm{~min}^{-1}$. The recorded chromatograms displayed peaks associated with maleic acid at $t_{\mathrm{r}}=8.1 \mathrm{~min}$ and acetic acid at $t_{\mathrm{r}}=15.1 \mathrm{~min}$.

The $\mathrm{SO}_{4}{ }^{2-}, \mathrm{Cl}^{-}, \mathrm{ClO}_{3}{ }^{-}$and $\mathrm{ClO}_{4}{ }^{-}$concentrations in treated solutions were measured by ion chromatography upon injection of $25 \mu \mathrm{L}$ aliquots into a Shimadzu 10Avp LC coupled to a Shimadzu CDD 10Avp conductivity detector. The LC was fitted with a Shim-Pack 
IC-A1S, $100 \mathrm{~mm} \times 4.6 \mathrm{~mm}$, anionic column at $40{ }^{\circ} \mathrm{C}$ and the mobile phase was a $2.6 \mathrm{mM}$ phthalic and $2.4 \mathrm{mM}$ tris(hydroxymethyl)aminomethane $(\mathrm{pH}=4.0)$ solution circulating at $1.5 \mathrm{~mL} \mathrm{~min}^{-1}$. For $\mathrm{NO}_{3}{ }^{-}$determination, the mobile phase containing boric acid, sodium gluconate, sodium tetraborate, acetonitrile, butanol and glycerine was eluted at $2.0 \mathrm{~mL} \mathrm{~min}{ }^{-1}$. The $\mathrm{NH}_{4}{ }^{+}$content was measured spectrophotometrically according to the standard indophenol blue reaction.

\section{Results and discussion}

\subsection{Characterization of the Ir-Sn-Sb oxide electrode}

Fig. S1a of Supplementary material depicts representative SEM images at magnifications of $1000 \times$ and $20,000 \times$ for the Ir-Sn-Sb oxide coating onto the Ti substrate, as obtained by the Pechini method. A good coverage and high adherence was revealed to the naked eye. A compact and uniformly distributed oxide layer can be observed at $1000 \times$, evidencing a certain roughness at $20,000 \times$. The surface morphology presented some small cracks, as expected from thermal treatments that cause a rapid evolution of $\mathrm{CO}_{2}$ gas formed by the decomposition of the organic polymer $[19,55,56]$.

The metal content in the precursor solution (in atomic percent) was distributed as follows: 49.7 at.\% Ir, 49.7 at.\% Sn and 0.6 at.\% Sb. Worth mentioning, the $\mathrm{Ir} / \mathrm{Sn} / \mathrm{Sb}$ molar ratio was preserved in the prepared film, since EDX analysis revealed that the final coating contained 11.3 at.\% C, 64.1 at.\% O, 2.6 at.\% Cl, 10.0 at.\% Ir, 12.0 at.\% $\mathrm{Sn}$ and 0.06 at.\% $\mathrm{Sb}$ in average. The presence of $\mathrm{C}$ and $\mathrm{Cl}$ is due to residues from the polymer precursor utilized.

Fig. S1b of Supplementary material depicts the XRD pattern, from $15^{\circ}$ to $75^{\circ}$, of the electrode showing some crystallographic planes that can be related to $\mathrm{Ti}$, Ir and a mixed $\mathrm{Sn}-\mathrm{Sb}$ oxide. Ti metal peaks, which appear from the diffraction of the underlying substrate and not as a result of uncoated areas as confirmed from the absence of Ti peaks in the previous EDX analysis, are slightly shifted from the standard ones. This agrees with mechanical stress mainly induced by heating periods. On the other hand, a mixed metal oxide whose peaks differ from pure $\mathrm{SnO}_{2}$ is clearly distinguished. According to the standard diffraction pattern database (ICDD: 04-011-7759), a mixed Sn-Sb oxide matches quite well. However, since neither $\mathrm{IrO}_{\mathrm{x}}$ nor $\mathrm{Sb}_{2} \mathrm{O}_{5}$ have been found in the diffractograms, in contrast to other works reporting the preparation of Ir-Sn-Sb oxide coatings by thermal treatment, it seems more reasonable to assign these XRD peaks (1) to a highly intermixed $\mathrm{Ir}-\mathrm{Sn}-\mathrm{Sb}$ oxide that is present as a solid solution. This may be accounted for by the selected synthesis methodology, including annealing temperatures that favor the solid state diffusion of all metals to form the MMO. Note that at such high temperature, Ir is present not only as MMO, but some atoms segregate and appear as Ir metal as well. Although it is not easy to ensure the formation of Ir metal based on just a couple of peaks, this finding agrees with a work by Chen et al. [55].

\subsection{Generation of hydroxyl radicals and active chlorine by the Ir-Sn-Sb oxide anode}

Fig. 1a shows the EPR spectrum with the four characteristic bands of the $\cdot \mathrm{OH}-\mathrm{DMPO}$ adduct [53] that was detected when a $10 \mathrm{mM}$ DMPO solution at $\mathrm{pH} 3.0$ was electrolyzed with the synthesized Ir-Sn-Sb oxide anode at $j=20 \mathrm{~mA} \mathrm{~cm}^{-2}$ for $15 \mathrm{~min}$. However, the bands were very weak, suggesting that the concentration of active $\mathrm{M}($ - $\mathrm{OH})$ generated at the anode surface was only slightly higher than $1 \times 10^{-8} \mathrm{M}$, the threshold value that can be measured by this technique. This means that, as in the case of pure $\mathrm{IrO}_{2}$ mentioned in the
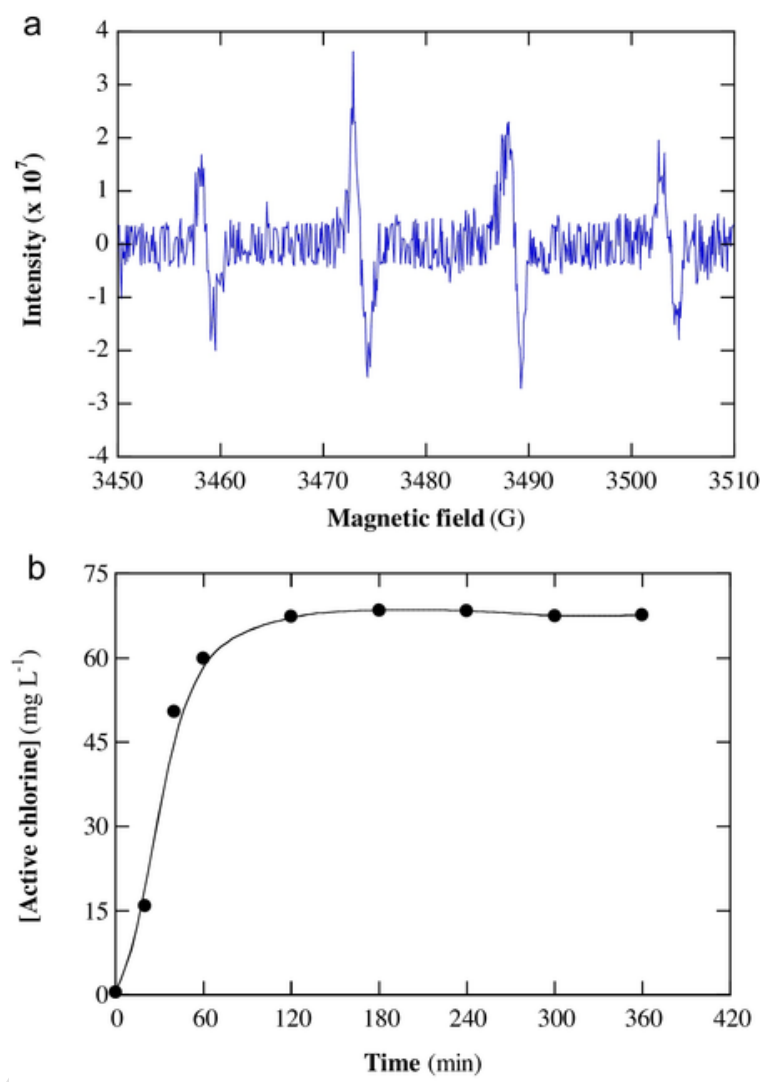

Fig. 1. (a) EPR spectrum of the ${ }^{\bullet} \mathrm{OH}-\mathrm{DMPO}$ adduct detected in $10 \mathrm{~mL}$ of a $10 \mathrm{mM}$ DMPO solution in $0.05 \mathrm{M} \mathrm{Na}_{2} \mathrm{SO}_{4}$ at $\mathrm{pH} 3.0$ and $30{ }^{\circ} \mathrm{C}$. An Ir-Sn-Sb oxide anode and a stainless steel cathode were used, both of $1 \mathrm{~cm}^{2}$, at a current density (j) of $20 \mathrm{~mA} \mathrm{~cm}$ for $15 \mathrm{~min}$. (b) Active chlorine concentration vs. electrolysis time for the treatment of $2.5 \mathrm{~L}$ of a $35 \mathrm{mM} \mathrm{NaCl}+25 \mathrm{mM} \mathrm{Na}_{2} \mathrm{SO}_{4}$ solution at $\mathrm{pH} 3.0$ and $30{ }^{\circ} \mathrm{C}$ using the flow plant with an electrochemical reactor equipped with a $24 \mathrm{~cm}^{2} \mathrm{Ir}-\mathrm{Sn}-\mathrm{Sb}$ oxide anode and a $24 \mathrm{~cm}^{2}$ stainless steel electrode at $j=150 \mathrm{~mA} \mathrm{~cm}^{-2}$ and liquid flow rate of $200 \mathrm{~L} \mathrm{~h}^{-1}$.

introduction section, the Ir-Sn-Sb oxide could be considered an "active" anode in EO, possessing a low ability to oxidize organic pollutants by chemisorbed $\mathrm{M}\left({ }^{\bullet} \mathrm{OH}\right)$.

In contrast, Fig. $1 \mathrm{~b}$ depicts a large accumulation of active chlorine in $2.5 \mathrm{~L}$ of a $35 \mathrm{mM} \mathrm{NaCl}+25 \mathrm{mM} \mathrm{Na}_{2} \mathrm{SO}_{4}$ solution at $\mathrm{pH} 3.0$ upon treatment in the flow plant with the reactor equipped with the prepared Ir-Sn-Sb oxide anode and a stainless steel cathode at $j=150 \mathrm{~mA} \mathrm{~cm}^{-2}$. As can be seen, a quasi-steady active chlorine concentration near $68 \mathrm{mg} \mathrm{L}^{-1}$ was obtained after $120 \mathrm{~min}$ of electrolysis. This is expected to occur exactly when the generation rate of this species from $\mathrm{Cl}^{-}$oxidation by Reactions (2) and (3) becomes equal to its destruction rate, which is mainly due to its ${ }^{\bullet} \mathrm{OH}-$ mediated or direct oxidation to $\mathrm{ClO}_{2}{ }^{-}$, $\mathrm{ClO}_{3}{ }^{-}$and $\mathrm{ClO}_{4}^{-}$ions via Reactions (11)-(13), as well as its cathodic reduction to $\mathrm{Cl}^{-}$via Reaction (14) [4,24]:

$$
\begin{aligned}
& \mathrm{ClO}^{-}+\mathrm{H}_{2} \mathrm{O} \rightarrow \mathrm{ClO}_{2}^{-}+2 \mathrm{H}^{+}+2 \mathrm{e}^{-} \\
& \mathrm{ClO}_{2}{ }^{-}+\mathrm{H}_{2} \mathrm{O} \rightarrow \mathrm{ClO}_{3}^{-}+2 \mathrm{H}^{+}+2 \mathrm{e}^{-} \\
& \mathrm{ClO}_{3}{ }^{-}+\mathrm{H}_{2} \mathrm{O} \rightarrow \mathrm{ClO}_{4}^{-}+2 \mathrm{H}^{+}+2 \mathrm{e}^{-} \\
& \mathrm{ClO}^{-}+\mathrm{H}_{2} \mathrm{O}+2 \mathrm{e}^{-} \rightarrow \mathrm{Cl}^{-}+2 \mathrm{OH}^{-}
\end{aligned}
$$


Based on the above results, active chlorine ( $\mathrm{HClO}$ at $\mathrm{pH} 3.0)$ is expected to be the pre-eminent oxidizing agent of Acid Yellow 36 and its by-products when treating $2.5 \mathrm{~L}$ of a dye solution by $\mathrm{EO}$ in the flow plant using the synthesized MMO anode in the presence of $\mathrm{Cl}^{-}$at acidic $\mathrm{pH}$, as presented in subsections below.

\subsection{Influence of the electrolyte on the electro-oxidation of acid yellow 36 solutions}

A first series of experiments was made to ascertain the decolorization and mineralization power of $\mathrm{M}\left({ }^{\bullet} \mathrm{OH}\right)$ and active chorine for the removal of Acid Yellow 36 and its by-products. Independent solutions of $0.46 \mathrm{mM}$ of dye in either $50 \mathrm{mM} \mathrm{NaClO}, 50 \mathrm{mM} \mathrm{Na}_{2} \mathrm{SO}_{4}$ or $35 \mathrm{mM} \mathrm{NaCl}+25 \mathrm{mM} \mathrm{Na}_{2} \mathrm{SO}_{4}$ at $\mathrm{pH} 3.0$ were prepared and treated in the flow plant by EO with an Ir-Sn-Sb oxide/stainless steel reactor at $j=50 \mathrm{~mA} \mathrm{~cm}^{-2}$ and liquid flow rate of $200 \mathrm{~L} \mathrm{~h}^{-1}$ for $360 \mathrm{~min}$. The starting reddish solutions turned black during electrolysis, probably due to the formation of highly colored polymeric products, becoming almost colorless at long time only in the mixed electrolyte. In these trials, the $\mathrm{pH}$ was not regulated because it did not vary significantly, just diminishing to a value near 2.8 at the end of the treatments. This suggests the production of acidic by-products like final short-chain linear carboxylic acids in all media $[4,21,23,30]$.

Fig. 2 a presents the percentage of color removal at $\lambda=437 \mathrm{~nm}$ against electrolysis time for the above assays. The decolorization was strongly inhibited in the $50 \mathrm{mM} \mathrm{NaClO}$ and $50 \mathrm{mM} \mathrm{Na}_{2} \mathrm{SO}_{4}$ solutions, only achieving $22.1 \%$ and $26.2 \%$ color removal, respectively. This means that the main oxidant in both cases, namely chemisorbed $\mathrm{M}\left({ }^{\bullet} \mathrm{OH}\right)$ generated at the Ir-Sn-Sb oxide anode surface, has a very low ability to remove the solution color at that wavelength, which can be related to either a low degradation rate of the dye with these radicals or the generation of large quantities of more recalcitrant colored by-products that interfere in the absorbance measurements, as suggested by the solution darkening. In contrast, the dye solution in $35 \mathrm{mM} \mathrm{NaCl}+25 \mathrm{mM} \mathrm{Na}_{2} \mathrm{SO}_{4}$ was continuously decolorized up to achieving $96.5 \%$ color reduction, in correspondence to an almost colorless final solution. This indicates that the active chlorine formed from Reactions (2) and (3) is able to quantitatively destroy the dye and its colored by-products, making the EO process efficient for decolorization.

The above absorbance decays were analyzed by kinetic equations related to simple reaction orders. No kinetic relationship was valid for describing the trends in $\mathrm{NaClO}_{4}$ and $\mathrm{Na}_{2} \mathrm{SO}_{4}$ media, whereas an excellent pseudo-first-order equation relating $\ln \left(A_{0} / A\right)$ with $t$ was followed in the mixed $\mathrm{Cl}^{-}$-containing electrolyte, as can be seen in Fig. $2 \mathrm{~b}$. The slope of this plot is the apparent rate constant for decolorization $\left(k_{\mathrm{dec}}\right)$, with a value of $0.0071 \mathrm{~min}^{-1}$ and an $R$-squared of 0.991 at $200 \mathrm{~L} \mathrm{~h}^{-1}$. This behavior suggests the attack of a constant concentration of the prevailing active chlorine species $(\mathrm{HClO})$ over colored pollutants in the bulk.

An opposite tendency was obtained for the TOC decay of the $0.46 \mathrm{mM}$ dye solution (100 $\left.\mathrm{mg} \mathrm{L}^{-1} \mathrm{TOC}\right)$. After 360 min of electrolysis at $j=50 \mathrm{~mA} \mathrm{~cm}^{-2}$ and liquid flow rate of $60 \mathrm{~L} \mathrm{~h}^{-1}$, about $20-21 \%$ TOC removal was found in $\mathrm{NaClO}_{4}$ and $\mathrm{Na}_{2} \mathrm{SO}_{4}$ media, but only $7.5 \%$ TOC was reduced using the mixed electrolyte. This finding demonstrates the higher oxidation ability of $\mathrm{M}\left({ }^{\bullet} \mathrm{OH}\right)$ compared to active chorine to mineralize the dye solution, which can be associated with a large production of refractory chloroderivatives in $35 \mathrm{mM}$ $\mathrm{NaCl}+25 \mathrm{mM} \mathrm{Na}_{2} \mathrm{SO}_{4}$ to yield a largely persistent mixture of organic compounds. These by-products are colorless, unlike those produced under the attack of $\mathrm{M}\left({ }^{*} \mathrm{OH}\right)$, which explains the almost total decolorization attained in the presence of $\mathrm{Cl}^{-}$ion.
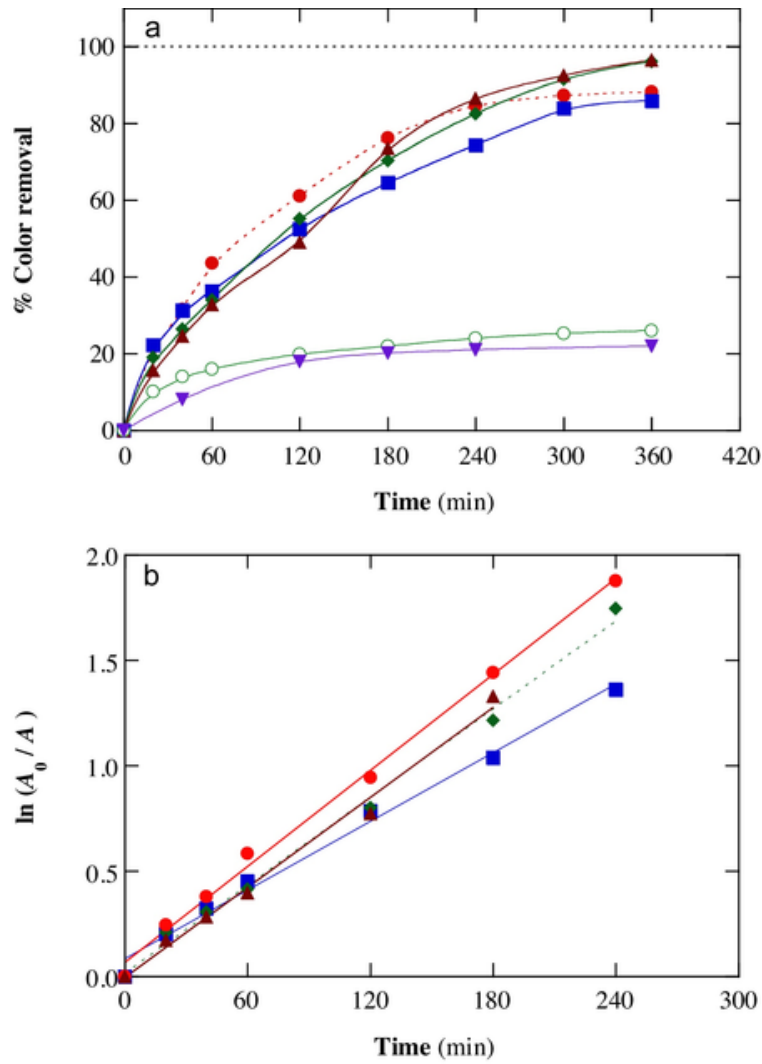

Fig. 2. (a) Change of percentage of color removal with electrolysis time for the electro-oxidation treatment of $2.5 \mathrm{~L}$ of a solution with $0.46 \mathrm{mM}$ Acid Yellow 36 at pH 3.0 and $30{ }^{\circ} \mathrm{C}$ in the flow plant at $j=50 \mathrm{~mA} \mathrm{~cm}^{-2}$. Medium: ( $) 50 \mathrm{mM} \mathrm{NaClO}_{4}$ and $(\mathrm{O}$ ) $50 \mathrm{mM} \mathrm{Na}_{2} \mathrm{SO}_{4}$ at $200 \mathrm{~L} \mathrm{~h}^{-1}$, or $35 \mathrm{mM} \mathrm{NaCl}+25 \mathrm{mM} \mathrm{Na}_{2} \mathrm{SO}_{4}$ at liquid flow rate: ) $60 \mathrm{~L} \mathrm{~h}^{-1}$, ( ) $120 \mathrm{~L} \mathrm{~h}^{-1}$, ( ) $150 \mathrm{~L} \mathrm{~h}^{-1}$ and (A) $200 \mathrm{~L} \mathrm{~h}^{-1}$. (b) Pseudo-first-order kinetics for the decolorization processes in $35 \mathrm{mM} \mathrm{NaCl}+25 \mathrm{mM} \mathrm{Na}_{2} \mathrm{SO}_{4}$. (For interpretation of the references to colour in this figure legend, the reader is referred to the web version of this article.)

From the above results, the quickest decolorization of the dye solution was achieved in $35 \mathrm{mM} \mathrm{NaCl}+25 \mathrm{mM} \mathrm{Na}_{2} \mathrm{SO}_{4}$. This medium was then selected to examine the influence of the main operation variables on the EO treatment in the flow plant.

\subsection{Effect of operation variables on acid yellow 36 electro-oxidation in the mixed electrolyte}

The liquid flow rate is an important variable in EO because it determines the mass transport of the reactants toward the anode as well as the oxidation rate of both, $\mathrm{Cl}^{-}$and active chlorine. The effect of this parameter was examined for the degradation of $0.46 \mathrm{mM}$ Acid Yellow 36 in the mixed electrolyte at $\mathrm{pH} 3.0$ and $j=50 \mathrm{~mA} \mathrm{~cm}{ }^{-2}$. As can be seen in Fig. 2a, a quite similar decolorization rate was obtained under all conditions tested, finally attaining $88.2 \%, 86.1 \%, 96.1 \%$ and $96.5 \%$ color abatement at increasing volumetric flow rates of 60 , 120,150 and $200 \mathrm{~L} \mathrm{~h}^{-1}$ (linear velocity of the liquid of $9.25,18.52$, 23.15 and $30.86 \mathrm{~cm} \mathrm{~s}^{-1}$ ). The two higher liquid flow rates showed the largest decolorization, although the color disappearance always followed analogous trends. This is indicative of the pre-eminent reaction of the dye and its colored by-products with active chlorine in the bulk, with little influence of the mass transport of $\mathrm{Cl}^{-}$ions toward the Ir-Sn-Sb oxide anode surface to be oxidized via Reaction (2). Fig. $2 b$ shows the good straight lines determined for these trials assuming that the absorbance decay at $\lambda=437 \mathrm{~nm}$ obeyed a pseudo- 
first-order kinetics. Table 2 summarizes the similar $k_{\mathrm{dec}}$ values thus calculated with $R^{2}>0.990$ in all cases. An average $k_{\mathrm{dec}}$ value of $0.0073 \pm 0.0002 \mathrm{~min}^{-1}$ was obtained at $j=50 \mathrm{~mA} \mathrm{~cm}^{-2}$, disregarding the slightly lower value obtained at $120 \mathrm{~L} \mathrm{~h}^{-1}$. In contrast, Table 2 shows a progressive enhancement in TOC reduction at higher liquid flow rate from $7.5 \%$ at $60 \mathrm{~L} \mathrm{~h}^{-1}$ to $18.0 \%$ at $200 \mathrm{~L} \mathrm{~h}^{-1}$, resulting in raising MCE values from $4.0 \%$ to $9.5 \%$. The improvement of mineralization as the liquid flow rate grew can be accounted for by: (i) the smaller contribution of parasitic Reactions (11)-(13) at the anode because of the shorter residence time of the liquid in the electrochemical reactor, in agreement with its higher linear velocity, and/or (ii) the enhanced mass transport of organic molecules toward the anode surface. Consequently, the reaction between organics and generated active chlorine in the large solution volume of the reservoir as well as that with ${ }^{\bullet} \mathrm{OH}$ at the anode are promoted. According to these findings, a liquid flow rate of $200 \mathrm{~L} \mathrm{~h}^{-1}$ was chosen to investigate the effect of $j$ and dye concentration on the performance of the EO process.

Fig. 3a highlights the gradual upgrading of color loss from a $0.46 \mathrm{mM}$ dye solution in the mixed electrolyte when $j$ rose from 20 to $150 \mathrm{~mA} \mathrm{~cm}^{-2}$. After $360 \mathrm{~min}$ of electrolysis, $91.4 \%$ and $96.5 \%$ color decay were attained at 20 and $50 \mathrm{~mA} \mathrm{~cm}^{-2}$, respectively, whereas total decolorization was achieved at that time at $100 \mathrm{~mA} \mathrm{~cm}{ }^{-2}$ and in only $240 \mathrm{~min}$ operating at $150 \mathrm{~mA} \mathrm{~cm}^{-2}$. This tendency can be ascribed to the progressively larger production of active chlorine as result of the acceleration of $\mathrm{Cl}^{-}$oxidation at the anode from Reaction (2). The excellent linear $\ln \left(A_{0} / A\right)$-t plots obtained for these trials are depicted in Fig. $3 \mathrm{~b}$. The $k_{\mathrm{dec}}$ values then increased from 0.0061 to $0.021 \mathrm{~min}^{-1}$, with $R^{2}>0.987$, as can be seen in Table 2 . The data given in this table also show a growing TOC abatement from $13.2 \%$ to $28.7 \%$ upon a $j$ increase from 20 to $150 \mathrm{~mA} \mathrm{~cm}^{-2}$, in agreement with the larger production of both, active chlorine and ${ }^{\bullet} \mathrm{OH}$. In contrast, the opposite trend can be observed for the corresponding MCE values, which dropped from $17.4 \%$ to $5.0 \%$ within that $j$-range. This behavior can be related to a progressive loss of the relative amount of: (i) active chlorine accumulated, due to the larger extent of its parasitic Reactions (11)-(13), and (ii) ${ }^{\circ} \mathrm{OH}$ at the anode surface, as a result of self-destruction reactions. All this eventually diminishes the destruction of organics, making the EO process more inefficient. This also agrees with the low rise (3.4-fold) of $k_{\mathrm{dec}}$ for a 7.5 -fold growth of $j$ (see Table 2).

The oxidation power of EO was further explored for dye contents between 0.23 and $0.92 \mathrm{mM}$ in the mixed electrolyte at $\mathrm{pH} 3.0$, $j=150 \mathrm{~mA} \mathrm{~cm}^{-2}$ and liquid flow rate of $200 \mathrm{~L} \mathrm{~h}^{-1}$. In these assays, the decay of the dye concentration was determined by reversed-phase HPLC. Fig. 4 reveals the complete dye disappearance at increasing times of 40,90 and $180 \mathrm{~min}$ for $0.23,0.46$ and $0.92 \mathrm{mM}$, respectively. This is the expected trend when an almost constant amount of oxidant is generated in the system, thus requiring a larger timer to remove greater amounts of the dye. The inset of Fig. 4 presents the good linear correlations found for the concentration decays assuming a pseudo-first-order oxidation reaction for Acid Yellow 36. The apparent rate constant for dye removal $\left(k_{1}\right)$ decreased from $0.146 \mathrm{~min}^{-1}$

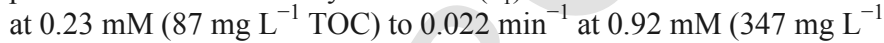
TOC), as can be seen in Table 2. This means that the dye decay did not actually agree with a pseudo-first-order process because in such a case, $k_{1}$ should be independent of the initial concentration. Nevertheless, this behavior corroborates the reaction of the dye molecules with a constant concentration of active chlorine species at each Acid Yellow 36 concentration, and suggests a complex process since oxidants not only react with the dye, but also with its oxidation by-products. Comparison of the results for the $0.46 \mathrm{M}$ solution of Figs. 3a and 4 allows inferring that decolorization was much slower than the dye abatement, with $k_{\mathrm{dec}}=0.021 \mathrm{~min}^{-1}<k_{1}=0.056 \mathrm{~min}^{-1}$. This suggests the formation of large amounts of colored by-products that are more slowly destroyed by active chlorine than the dye. In addition, a closer look to Table 2 reveals a decrease of the percentage of TOC removal from $40.0 \%$ at $0.23 \mathrm{mM}$ to $18.5 \%$ at $0.92 \mathrm{mM}$, as expected from the presence of greater organic load. However, the MCE values underwent a progressive enhancement from $3.5 \%$ to $6.6 \%$, which may be explained by the smaller extent at which parasitic reactions occur because of the enhancement of positive reaction events between the organics and the oxidants, thereby causing larger TOC abatements.

From this subsection, one can establish that the most efficient EO treatment of Acid Yellow 36 is achieved operating at low $j$ values and high dye contents, although in all cases a partial mineralization was found using an Ir-Sn-Sb oxide anode.

Table 2

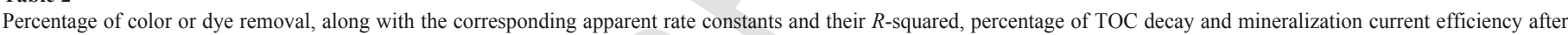

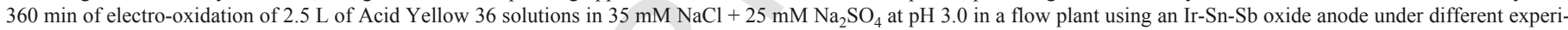
mental conditions.

\begin{tabular}{|c|c|c|c|c|c|c|c|c|}
\hline $\begin{array}{l}{[\text { dye] }} \\
\left(\mathrm{mg} \mathrm{L}^{-1}\right)\end{array}$ & $\begin{array}{l}{\left[\mathrm{Fe}^{2+}\right]} \\
(\mathrm{mM})\end{array}$ & $\begin{array}{l}j \\
\left(\mathrm{~mA} \mathrm{~cm}^{-2}\right)\end{array}$ & Liquid flow rate $\left(\mathrm{L} \mathrm{h}^{-1}\right)$ & $\begin{array}{l}k \\
\left(\min ^{-1}\right)\end{array}$ & $R^{2}$ & $\%$ color removal & $\%$ TOC removal & $\begin{array}{l}\text { MCE } \\
(\%)\end{array}$ \\
\hline 87 & - & 150 & 200 & $0.146^{\mathrm{a}}$ & 0.988 & $-^{\mathrm{c}}$ & 40.0 & 3.5 \\
\hline 173 & - & 20 & 200 & $0.0061^{\mathrm{b}}$ & 0.993 & 91.4 & 13.2 & 17.4 \\
\hline 173 & - & 50 & 60 & $0.0075^{\mathrm{b}}$ & 0.996 & 88.2 & 7.5 & 4.0 \\
\hline 173 & - & 50 & 120 & $0.0054^{\mathrm{b}}$ & 0.990 & 85.9 & 9.2 & 4.8 \\
\hline 173 & - & 50 & 150 & $0.0070^{\mathrm{b}}$ & 0.995 & 96.1 & 17.9 & 9.4 \\
\hline 173 & - & 50 & 200 & $0.0071^{\mathrm{b}}$ & 0.991 & 96.5 & 18.0 & 9.5 \\
\hline 173 & - & 100 & 200 & $0.013^{\mathrm{b}}$ & 0.994 & 100 & 21.0 & 5.5 \\
\hline 173 & & 150 & 200 & $0.056^{\mathrm{a}} 0.021^{\mathrm{b}}$ & $\begin{array}{c}0.987 \\
0.998\end{array}$ & $100^{\mathrm{d}}$ & 28.7 & 5.0 \\
\hline 173 & $1 \mathrm{mM}$ & 150 & 200 & $\begin{array}{c}0.068^{\mathrm{a}} \\
0.038^{\mathrm{b}}\end{array}$ & $\begin{array}{c}0.996 \\
0.989\end{array}$ & $100^{\mathrm{e}}$ & 33.0 & 5.8 \\
\hline 173 & $1 \mathrm{mM}+\mathrm{UVA}$ & 150 & 200 & $\begin{array}{c}0.067^{\mathrm{a}} \\
0.043^{\mathrm{b}}\end{array}$ & $\begin{array}{c}0.994 \\
0.990\end{array}$ & $100^{\mathrm{e}}$ & 36.8 & 6.5 \\
\hline 357 & - & 150 & 200 & $0.022^{\mathrm{a}}$ & 0.997 & $-^{\mathrm{c}}$ & 18.5 & 6.6 \\
\hline
\end{tabular}

\footnotetext{
${ }^{\text {a }}$ Pseudo-first-order rater constant for dye removal $\left(k_{1}\right)$.

b Pseudo-first-order rater constant for decolorization $\left(k_{\mathrm{dec}}\right)$.

c Not determined.

d At $240 \mathrm{~min}$

e At $120 \mathrm{~min}$.
} 

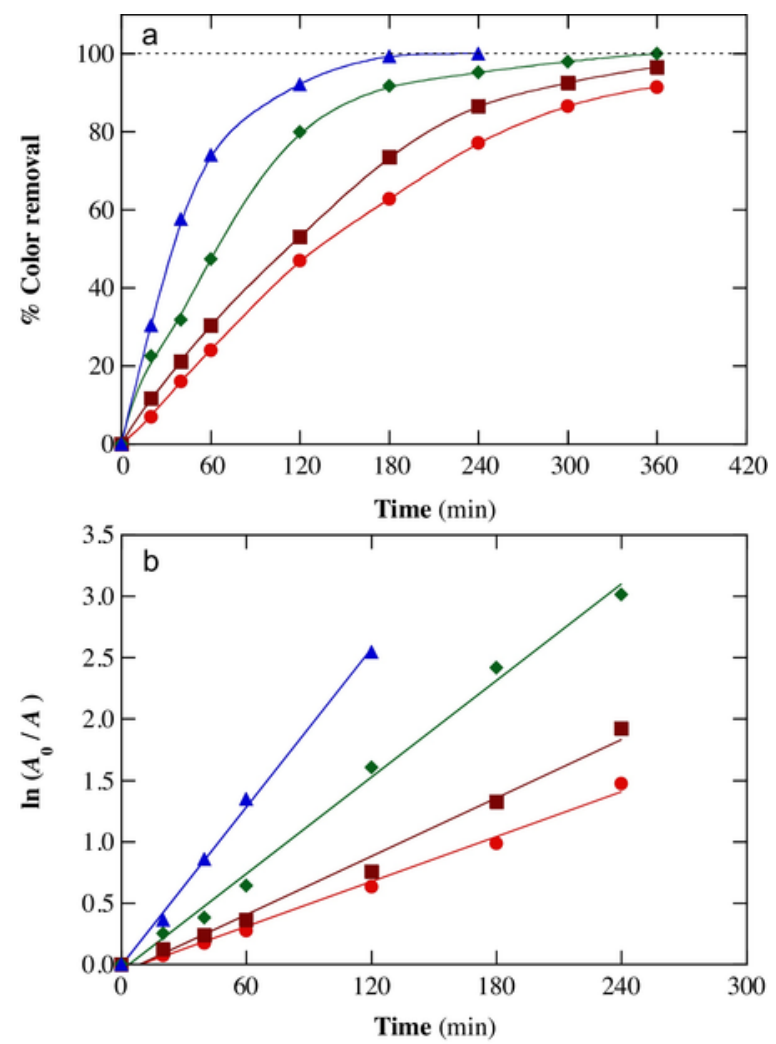

Fig. 3. (a) Effect of current density on the percentage of color removal with electrolysis time for the electro-oxidation treatment of $2.5 \mathrm{~L}$ of $0.46 \mathrm{mM}$ Acid Yellow 36 solution in $35 \mathrm{mM} \mathrm{NaCl}+25 \mathrm{mM} \mathrm{Na}_{2} \mathrm{SO}_{4}$ at $\mathrm{pH} 3.0$ and $30^{\circ} \mathrm{C}$ in the flow plant at $200 \mathrm{~L} \mathrm{~h}^{-1}$. Current density: (O) $20 \mathrm{~mA} \mathrm{~cm}^{-2}$, (口) $50 \mathrm{~mA} \mathrm{~cm}^{-2}$, (४) $100 \mathrm{~mA} \mathrm{~cm}^{-2}$ and (A) $150 \mathrm{~mA} \mathrm{~cm}^{-2}$. (b) Kinetic analysis considering a pseudo-first-order decolorization reaction. (For interpretation of the references to colour in this figure legend, the reader is referred to the web version of this article.)

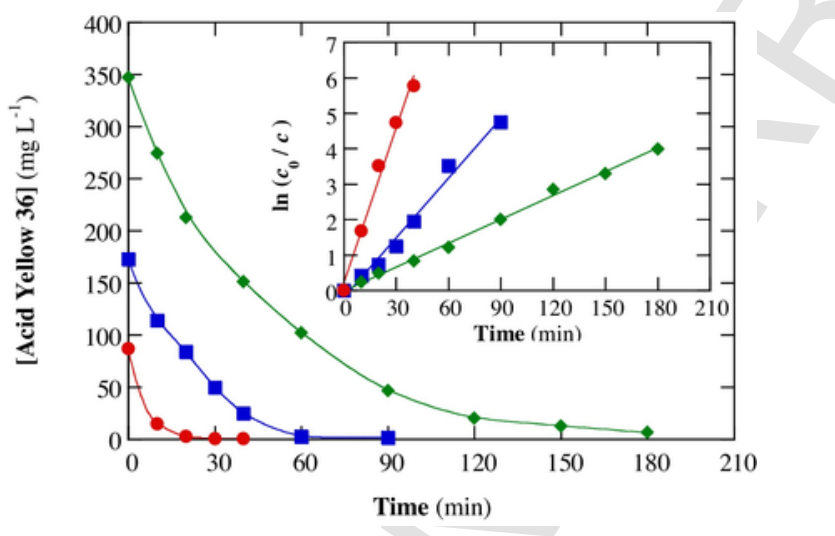

Fig. 4. Concentration dye decay vs. electrolysis time treating $2.5 \mathrm{~L}$ of $(\mathrm{O}) 0.23 \mathrm{mM}$, (D) $0.46 \mathrm{mM}$ and $0.92 \mathrm{mM}$ Acid Yellow 36 solutions in $35 \mathrm{mM} \mathrm{NaCl}+25 \mathrm{mM}$ $\mathrm{Na}_{2} \mathrm{SO}_{4}$ at $\mathrm{pH} 3.0$ and $30{ }^{\circ} \mathrm{C}$ by electro-oxidation in the flow plant at $j=150 \mathrm{~mA} \mathrm{~cm}^{-2}$ and liquid flow rate of $200 \mathrm{~L} \mathrm{~h}^{-1}$. The inset panel presents the corresponding kinetic analysis considering a pseudo-first-order reaction for the dye. (For interpretation of the references to colour in this figure legend, the reader is referred to the web version of this article.)

\subsection{Fenton-like process in the mixed electrolyte}

The results obtained in previous subsections lay the foundations to clarify if a Fenton-like process involving ${ }^{\bullet} \mathrm{OH}$ generation from Reaction (5) can occur in the presence of $\mathrm{Fe}^{2+}$ in the mixed electrolyte. To this aim, $2.5 \mathrm{~L}$ of a $0.46 \mathrm{mM}$ dye solution in $35 \mathrm{mM} \mathrm{NaCl}+25 \mathrm{mM}$ $\mathrm{Na}_{2} \mathrm{SO}_{4}$ with $1.0 \mathrm{mM} \mathrm{Fe}{ }^{2+}$ at $\mathrm{pH} 3.0$ were electrolyzed in the flow plant operating at $j=150 \mathrm{~mA} \mathrm{~cm}^{-2}$ and liquid flow rate $200 \mathrm{~L} \mathrm{~h}^{-1}$. These assays were performed without and with UVA irradiation, i.e., under EF-like and PEF-like conditions, respectively. A slight acidification to $\mathrm{pH}$ 2.7-2.8 was observed after $360 \mathrm{~min}$ of both treatments.

Fig. 5a demonstrates a clear enhancement of the percentage of color removal in the EF-like and PEF-like treatments as compared to the $\mathrm{EO}$ (i.e., in the absence of $\mathrm{Fe}^{2+}$ ). In the latter case, a time of $240 \mathrm{~min}$ was required to attain total decolorization at $\lambda=437 \mathrm{~nm}$, whereas in both EF-like and PEF-like processes, the color disappeared at a shorter time of ca. $120 \mathrm{~min}$. The quicker decolorization in the two latter cases can then be ascribed to the faster destruction of the dye and its colored by-products in the bulk under the competitive action of active chlorine formed from Reactions (2) and (3) and homogeneous ${ }^{\bullet} \mathrm{OH}$ originated from the Fenton-like Reaction (5). It is noteworthy that Fig. 5a reveals just a slight acceleration of the color removal in the PEF-like process if compared to the EF-like one, suggesting a minor contribution of additional ${ }^{\bullet} \mathrm{OH}$ induced by the photolytic Reaction (7) to dye degradation, along with photostability of the dye and its colored by-products. A pseudo-first-order equation was verified for all absorbance decays at $\lambda=437 \mathrm{~nm}$, as can be seen in Fig. $5 \mathrm{~b}$ and Table 2 . As expected, the $k_{\mathrm{dec}}$ value for the PEF-like treatment $\left(0.043 \mathrm{~min}^{-1}\right)$ was only slightly higher than that of the EF-like one $\left(0.038 \mathrm{~min}^{-1}\right)$, being both values much greater than that of the EO process $\left(0.021 \mathrm{~min}^{-1}\right)$.

A similar comparative profile was found for the removal of the dye concentration. Fig. 5c highlights a quite similar dye decay in both Fenton-like processes, being much more rapid than that in EO. Total dye disappearance was attained after 60 and 90 min of electrolysis, which were much shorter times than those needed for total decolorization (see Fig. 5a). This finding corroborates the generation of colored by-products that hamper the loss of solution color. From the pseudo-first-order relationships followed by the above concentration decays and presented in the inset of Fig. $5 \mathrm{c}$, a $k_{1}=0.067 \pm 0.001 \mathrm{~min}^{-1}$ was determined for both, EF-like and PEF-like treatments, a value higher than $0.056 \mathrm{~min}^{-1}$ obtained for EO (see Table 2). The fact that the dye was removed with same $k_{1}$-value for both Fenton-like processes confirms that the production of ${ }^{\bullet} \mathrm{OH}$ by the photolytic Reaction (7) was really small. This allows concluding that UVA light can basically serve to induce the photodegradation of some colored by-products to yield a slightly faster decolorization in the PEF-like process.

The aforementioned results suggest the existence of the Fenton-like Reaction (5) that allows the generation of $\bullet \mathrm{OH}$ and hence, it accelerates the dye and color removal. Additional confirmation of this reaction was found from the corresponding percentage of TOC removal after $360 \mathrm{~min}$ of electrolysis, listed in Table 2 . This value grew from $28.7 \%$ in EO to $33.0 \%$ in EF-like and $36.8 \%$ in PEF-like processes, with the concomitant rise in MCE. The greater decontamination by the EF-like treatment compared to the EO one can be associated with the extra ${ }^{\circ} \mathrm{OH}$ production via the Fenton-like Reaction (5), which accelerates the mineralization of by-products generated. However, the high stability of intermediates, especially those complexed with $\mathrm{Fe}$ (III), impedes a more pronounced enhancement. In contrast, the superior oxidation ability of the PEF-like process can be 

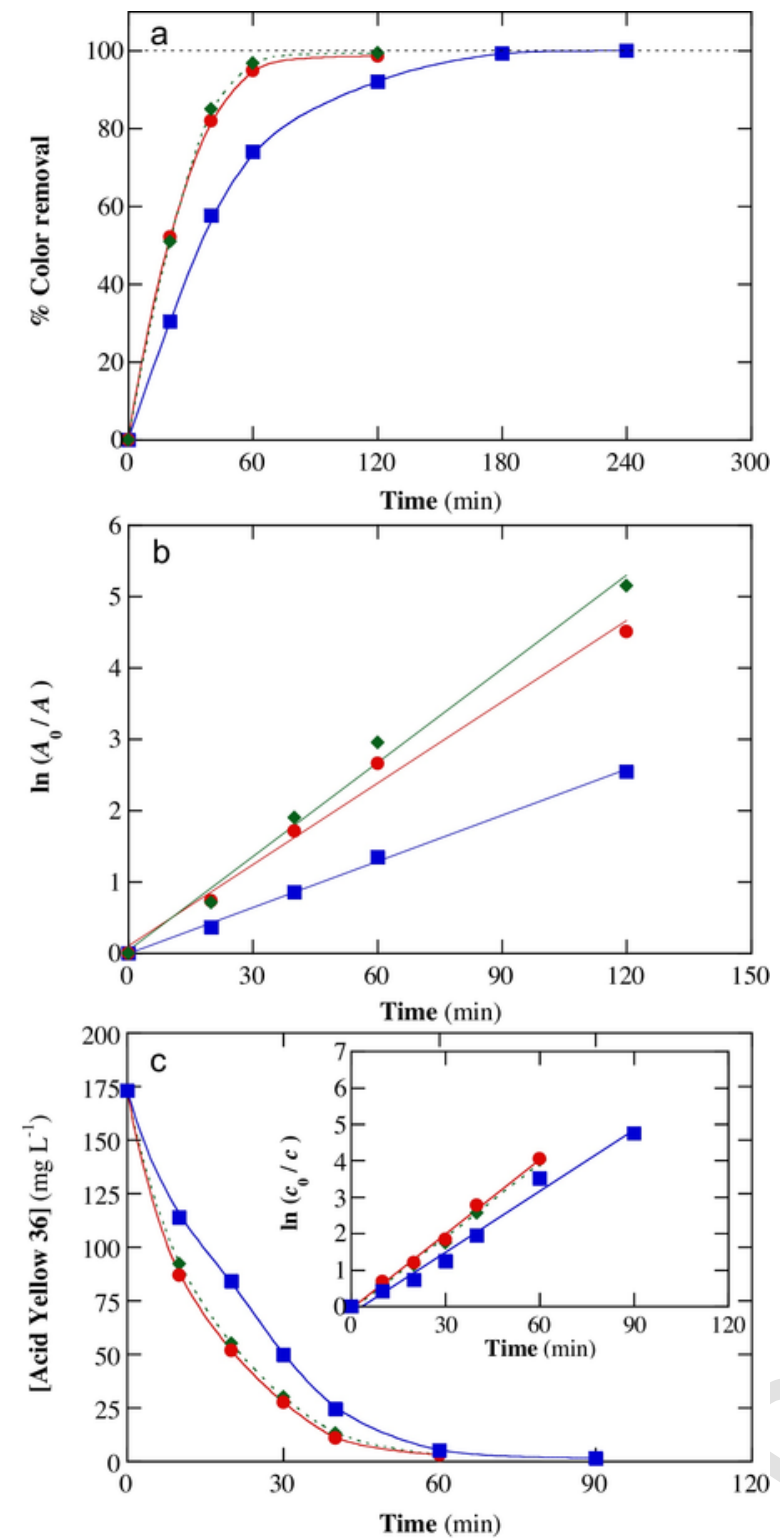

Fig. 5. (a) Variation of the percentage of color removal with electrolysis time for the electro-oxidation of $2.5 \mathrm{~L}$ of $0.46 \mathrm{mM}$ Acid Yellow 36 solutions in $35 \mathrm{mM}$ $\mathrm{NaCl}+25 \mathrm{mM} \mathrm{Na}_{2} \mathrm{SO}_{4}(\square)$ without $\mathrm{Fe}^{2+}$ addition and with (O) $1.0 \mathrm{mM} \mathrm{Fe}^{2+}$ (EF-like process) or $(\diamond) 1.0 \mathrm{mM} \mathrm{Fe}{ }^{2+}+\mathrm{UVA}$ irradiation (PEF-like process) at $\mathrm{pH} 3.0$ and $30{ }^{\circ} \mathrm{C}$ in the flow plant at $j=150 \mathrm{~mA} \mathrm{~cm}^{-2}$ and liquid flow rate of $200 \mathrm{~L} \mathrm{~h}^{-1}$. (b) Pseudo-first-order kinetic analysis for the three decolorization processes. (c) Dye concentration decay for the same assays. The kinetic analysis assuming a pseudo-first-order reaction for Acid Yellow 36 is shown in the inset panel. (For interpretation of the references to colour in this figure legend, the reader is referred to the web version of this article.)

related to the production of more ${ }^{\bullet} \mathrm{OH}$ from Reaction (5) and the additional photolysis of certain refractory by-products, including Fe(III) complexes, upon the action of UVA radiation, thus enhancing the mineralization process $[15,24,30]$.

\subsection{Detection of final carboxylic acids and fate of inorganic ions}

Ion-exclusion HPLC analysis of the $0.46 \mathrm{mM}$ dye solution in mixed electrolyte treated by EO and EF-like processes revealed the formation of maleic and acetic acids. It is known that both carboxylic acids are generated from the oxidative cleavage of the aromatic rings of Acid Yellow $36[4,15]$, being the acids transformed into the final oxalic and formic acids, which were not detected in the above trials. This fact suggests a preferential reaction of maleic and acetic acids with active chlorine, leading to chloroderivatives different from oxalic and formic acids. Fig. 6a shows a slow and continuous accumulation of maleic acid up to 3.5 and $2.4 \mathrm{mg} \mathrm{L}^{-1}$ at the end of EO and EF-like treatments, whereas a larger content of 34.7 and $30.3 \mathrm{mg} \mathrm{L}^{-1}$ was finally determined for acetic acid. Note that the accumulation of acetic acid began at much shorter times in the EF-like process due to the faster oxidation of some primary intermediates with additional ${ }^{*}$ $\mathrm{OH}$ originated for Fenton-like Reaction (5). A simple mass balance revealed that the final solutions in such treatments contained 15.3 and $13.1 \mathrm{mg} \mathrm{L}^{-1}$ of TOC, only representing $21.4 \%$ and $19.5 \%$ of the remaining organic load. Hence, a large quantity of other undetected persistent by-products was produced during the dye degradation in the mixed electrolyte.

To elucidate the nature of generated by-products, the inorganic ions lost or released after $360 \mathrm{~min}$ of EF-like degradation were determined. Fig. 6b shows a large removal of $\mathrm{Cl}^{-}$from the starting mixed electrolyte since it was oxidized to $\mathrm{HClO}$ via Reactions (2) and (3), followed by oxidation of $\mathrm{HClO}$ to $\mathrm{ClO}_{3}{ }^{-}$and $\mathrm{ClO}_{4}{ }^{-}$from Reactions (11)-(13). $\mathrm{No}^{\mathrm{ClO}_{2}}{ }^{-}$was detected due to its instability in acidic conditions. Since the sum of $\mathrm{ClO}_{3}{ }^{-}$and $\mathrm{ClO}_{4}{ }^{-}$contents was $8.95 \mathrm{mM}$, a value lower than $9.86 \mathrm{mM} \mathrm{Cl}^{-}$lost, one can infer that about $0.91 \mathrm{mM}$ of chlorine was present in the final solution either as active chlorine or chloro-organics. Note that this value is lower than $1.27 \mathrm{mM}$ of ac-
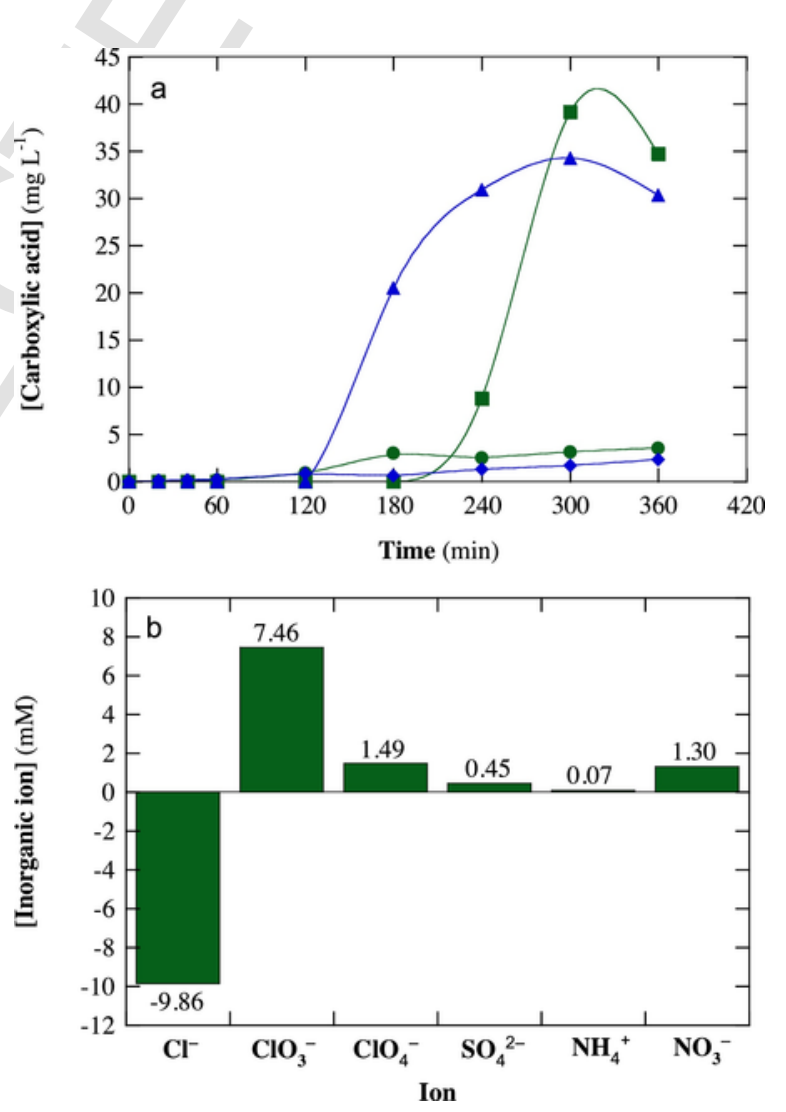

Fig. 6. (a) Time course of $(O$,$) maleic and ( , ) acetic acids detected during the$ electro-oxidation treatment of $2.5 \mathrm{~L}$ of $0.46 \mathrm{mM}$ Acid Yellow 36 solutions in $35 \mathrm{mM}$ $\mathrm{NaCl}+25 \mathrm{mM} \mathrm{Na}_{2} \mathrm{SO}_{4},\left(\mathrm{O}\right.$, without $\mathrm{Fe}^{2+}$ addition or with $(\Delta, \mathbf{A}) 1.0 \mathrm{mM} \mathrm{Fe}$ (EF-like process) at $\mathrm{pH} 3.0$ and $30^{\circ} \mathrm{C}$ using the flow plant at $j=150 \mathrm{~mA} \mathrm{~cm}{ }^{-2}$ and liquid flow rate of $200 \mathrm{~L} \mathrm{~h}^{-1}$. (b) Concentration of released or accumulated inorganic ions at $360 \mathrm{~min}$ for the EF-like trial. (For interpretation of the references to colour in this figure legend, the reader is referred to the web version of this article.) 
tive chlorine found upon electrolysis of the raw background electrolyte under the same conditions (see Fig. 1b), thus confirming its ability to attack the dye and its by-products. It is also remarkable the overall conversion of the initial $\mathrm{S}$ of the dye $(0.46 \mathrm{mM})$ into $\mathrm{SO}_{4}{ }^{2-}$ and of its initial $\mathrm{N}(1.38 \mathrm{mM})$ pre-eminently as $\mathrm{NO}_{3}{ }^{-}$and, to a much slower extent, as $\mathrm{NH}_{4}^{+}$, as stated in Reaction (10). These findings confirm the loss of all the heteroatoms of the dye during its degradation and, consequently, linear chlorinated compounds and non-chlorinated carboxylic acids could be preferentially produced from the breaking of the benzenic moieties.

\section{Conclusions}

The Ir-Sn-Sb oxide anode prepared by the Pechini method showed a low production of chemisorbed $\mathrm{M}\left({ }^{\bullet} \mathrm{OH}\right)$, but a large ability to generate active chlorine (as $\mathrm{HClO}$ ) in a $\mathrm{Cl}^{-}$-containing electrolyte. A quick decolorization of Acid Yellow 36 solutions was found in this medium by $\mathrm{EO}$ due to action of $\mathrm{HClO}$ over the colored by-products, although the accumulation of chloroderivatives impeded the complete mineralization. In contrast, the color was poorly removed in $\mathrm{NaClO}_{4}$ or $\mathrm{Na}_{2} \mathrm{SO}_{4}$ media because of the small contribution of $\mathrm{M}\left({ }^{\bullet} \mathrm{OH}\right)$. The liquid flow rate in the plant did not affect significantly the decolorization rate, but its increase caused a higher TOC removal due to the deceleration of parasitic reactions of active chlorine. This can also explain the better performance of the EO process with decreasing $j$ and increasing dye concentration. The absorbance and dye concentration abatements obeyed a pseudo-first-order kinetics, with greater apparent rate constant in the latter case. The decolorization, dye concentration decay and TOC removal were enhanced by adding $1.0 \mathrm{mM} \mathrm{Fe}^{2+}$ to the dye solution in the mixed electrolyte, which is a clear evidence of the formation of ${ }^{\bullet} \mathrm{OH}$ in the bulk from the Fenton-like reaction between generated $\mathrm{HClO}$ and added $\mathrm{Fe}^{2+}$. The PEF-like treatment showed larger mineralization ability than the EF-like one by the additional photolysis of intermediates under UVA irradiation. Maleic and acetic acids were detected as final short-chain linear carboxylic acids. High contents of $\mathrm{ClO}_{3}{ }^{-}$and $\mathrm{ClO}_{4}{ }^{-}$were formed from $\mathrm{HClO}$ oxidation, whereas the initial S and $\mathrm{N}$ were transformed into $\mathrm{SO}_{4}{ }^{2-}$ and $\mathrm{NO}_{3}{ }^{-}$, respectively.

\section{Acknowledgements}

Financial support from project CTQ2016-78616-R (MINECO, Feder, EU) is acknowledged. The authors would also like to thank financial support under project 240522 (CONACYT, Mexico) and project 869/2016 (University of Guanajuato, Mexico). Z. Aguilar is grateful to CONACYT for the PhD scholarship No. 421053 granted.

\section{Appendix A. Supplementary data}

Supplementary data associated with this article can be found, in the online version, at http://dx.doi.org/10.1016/j.apcatb.2017.01.006.

\section{References}

[1] D. Rajkumar, J.G. Kim, J. Hazard. Mater. B 136 (2006) 203-212.

[2] T. Robinson, G. McMullan, R. Marchant, P. Nigam, Bioresour. Technol. 77 (2001) 247-255.

[3] E. Forgacs, T. Cserháti, G. Oros, Environ. Int. 30 (2004) 953-971.

[4] E. Brillas, C.A. Martínez-Huitle, Appl. Catal B: Environ. 166-167 (2015) 603-643.

[5] H. Zollinger, Color Chemistry: Synthesis, Properties, and Applications of Organic Dyes and Pigments, VHCA and Wiley-VCH, Switzerland, 2003

[6] A.B. dos Santos, F.J. Cervantes, J.B. van Lier, Bioresour. Technol. 98 (2007) 2369-2385.
[7] S.M.A.G. Ulson de Souza, E. Forgiarini, A.A. Ulson de Souza, J. Hazard. Mater. 147 (2007) 1073-1078.

[8] K.P. Sharma, S. Sharma, S.P. Sharma, K. Singh, S. Kumar, R. Grover, P.K. Sharma, Chemosphere 69 (2007) 48-54.

[9] V.J.P. Vilar, L.X. Pinho, A.M.A. Pintor, R.A.R. Boaventura, Sol. Energy 85 (2011) 1927-1934.

[10] V. Khandegar, A.K. Saroha, J. Environ. Manage. 128 (2013) 949-963.

[11] C. Saez, M. Panizza, M.A. Rodrigo, G. Cerisola, J. Chem. Technol. Biotechnol. 82 (2007) $575-581$.

[12] M. Villanueva-Rodríguez, A. Hernández-Ramírez, J.M. Peralta-Hernández, E.R. Bandala, M.A. Quiroz-Alfaro, J. Hazard. Mater. 167 (2009) 1226-1230.

[13] A. Özcan, M.A. Oturan, N. Oturan, Y. Şahin, J. Hazard. Mater. 163 (2009) $1213-1220$.

[14] K. Cruz-González, O. Torres-López, A. García-León, J.L. Guzmán-Mar, L.H. Reyes, A. Hernández-Ramírez, J.M. Peralta-Hernández, Chem. Eng. J. 160 (2010) 199-206.

[15] E.J. Ruiz, C. Arias, E. Brillas, A. Hernández-Ramírez, J.M. Peralta-Hernández, Chemosphere 82 (2011) 495-501.

[16] S. Garcia-Segura, F. Centellas, C. Arias, J.A. Garrido, R.M. Rodríguez, P.L. Cabot, E. Brillas, Electrochim. Acta 58 (2011) 303-311.

[17] A.J. Méndez-Martínez, M.M. Dávila-Jiménez, O. Ornelas-Dávila, M.P. Elizalde-González, U. Arroyo-Abad, I. Sirés, E. Brillas, Electrochim. Acta 59 (2012) 140-149.

[18] J.M. Aquino, R.C. Rocha-Filho, M.A. Rodrigo, C. Sáez, P. Cañizares, Water. Air Soil Pollut. 224 (2013) 1397-1406.

[19] R. Chaiyont, C. Badoe, C. Ponce de León, J.L. Nava, F.J. Recio, I. Sirés, P. Herrasti, F.C. Walsh, Chem. Eng. Technol. 36 (2013) 123-129.

[20] A. El-Ghenymy, F. Centellas, J.A. Garrido, R.M. Rodríguez, I. Sirés, P.L. Cabot, E. Brillas, Electrochim. Acta 130 (2014) 568-576.

[21] I. Sirés, E. Brillas, M.A. Oturan, M.A. Rodrigo, M. Panizza, Environ. Sci. Pollut. Res. 21 (2014) 8336-8367.

[22] A. Thiam, E. Brillas, F. Centellas, P.L. Cabot, I. Sirés, Electrochim. Acta 173 (2015) 523-533.

[23] C.A. Martínez-Huitle, M.A. Rodrigo, I. Sirés, O. Scialdone, Chem. Rev. 115 (2015) 13362-13407.

[24] A. Thiam, I. Sirés, J.A. Garrido, R.M. Rodríguez, E. Brillas, J. Hazard. Mater. 290 (2015) 34-42.

[25] T.X.H. Le, M. Bechelany, S. Lacour, N. Oturan, M.A. Oturan, M. Cretin, Carbon 94 (2015) 1003-1011.

[26] A. Thiam, I. Sirés, J.A. Garrido, R.M. Rodríguez, E. Brillas, Sep. Purif. Technol. 140 (2015) 43-52

[27] S. Shukla, M.A. Oturan, Environ. Chem. Lett. 13 (2015) 157-172.

[28] A. Bedolla-Guzman, I. Sirés, A. Thiam, J.M. Peralta-Hernández, S. Gutiérrez-Granados, E. Brillas, Electrochim. Acta 206 (2016) 307-316.

[29] V.M. Vasconcelos, C. Ponce-de-León, J.L. Nava, M.R.V. Lanza, J. Electroanal, Chem. 765 (2016) 179-187.

[30] F.C. Moreira, R.A.R. Boaventura, E. Brillas, V.J.P. Vilar, Appl. Catal. B: Environ. 202 (2017) 217-261.

[31] B. Marselli, J. García-Gomez, P.A. Michaud, M.A. Rodrigo, C. Comninellis, J. Electrochem. Soc. 150 (2003) D79-D83.

[32] M. Panizza, G. Cerisola, Chem. Rev. 109 (2009) 6541-6569.

[33] G. Coria, I. Sirés, E. Brillas, J.L. Nava, Chem. Eng. J. 304 (2016) 817-825.

[34] E. Butrón, M.E. Juárez, M. Solis, M. Teutli, I. González, J.L. Nava, Electrochim. Acta 52 (2007) 6888-6894.

[35] J.L. Nava, F. Núñez, I. González, Electrochim. Acta 52 (2007) 3229-3235.

[36] W. Wu, Z.H. Huang, T.T. Lim, Appl. Catal. A: Gen. 480 (2014) 58-78.

[37] D.Z. Mijin, M.L. Avramov-Ivic, A.E. Onjia, B.N. Grgur, Chem. Eng. J. 204-206 (2012) 151-157.

[38] M.I. León, Z.G. Aguilar, J.L. Nava, J. Electrochem. Sci. Eng. 4 (2014) 247-258.

[39] N. Kishimoto, Y. Nakamura, M. Kato, H. Otsu, Chem. Eng. J. 260 (2015) 590-595.

[40] L.P. Candeias, M.R.L. Stanford, P. Wardman, Free Radic. Res. 20 (1994) $241-249$.

[41] A. Thiam, I. Sirés, E. Brillas, Water Res. 81 (2015) 178-187.

[42] S. Chen, Y. Zheng, S. Wang, X. Chen, Chem. Eng. J. 172 (2011) 47-51

[43] P.K. Malik, Dyes Pigments 56 (2003) 239-249.

[44] A. Mittal, V.K. Gupta, A. Malviya, J. Mittal, J. Hazard. Mater. 151 (2008) $821-832$.

[45] S. Mozia, A.W. Morawski, M. Toyoda, T. Tsumura, Chem. Eng. J. 150 (2009) $152-159$.

[46] A.R. Khataee, M. Safarpour, M. Zarei, S. Aber, J. Mol. Catal. A: Chem. 363-364 (2012) 58-68.

[47] S. Khezrianjoo, H.D. Revanasiddappa, J. Catal. (2013) 582058 (7 pp).

[48] H. Aghdasinia, R. Bagheri, B. Vahid, A. Khataee, Environ. Technol. 37 (2016) 2703-2712. 
[49] J. Macías-Sánchez, L. Hinojosa-Reyes, J.L. Guzmán-Mar, J.M. Peralta-Hernández, A. Hernández-Ramírez, Photochem. Photobiol. Sci. 10 (2011) 332-337.

[50] Y. Juang, E. Nurhayati, C. Huang, J.R. Pan, S. Huan, Sep. Purif. Technol. 120 (2013) 289-295.

[51] K. Cruz-González, O. Torres-López, A.M. García-León, E. Brillas, A. Hernández-Ramírez, J.M. Peralta-Hernández, Desalination 286 (2012) 63-68.

[52] M.P. Pechini, US Patent 3330697 A (1967).
[53] B. Borbón, M.T. Oropeza-Guzman, E. Brillas, I. Sirés, Environ. Sci. Pollut. Res. 21 (2014) 8573-8584.

[54] APWA, AWWA, WEF, Standard Methods for the Examination of Water and Wastewater, 21 st Ed. Method Number 4500-Cl Chlorine (residual)-G. DPD Colorimetric Method, American Public Health Association, Washington D.C, 2005. pp. 4-67-4-68..

[55] X. Chen, G. Chen, P.L. Yue, J. Phys. Chem. B 105 (2001) 4623-4628.

[56] S. Chen, Y. Zheng, S. Wang, X. Chen, Chem. Eng. J. 172 (2011) 47-51. 